\title{
Taking up the Gavel
}

\author{
Christoph U. Lehmann, President of IMIA
}

\section{Taking on the Task of IMIA President}

On my desk at Vanderbilt University, I proudly display the gavel of the IMIA President given to IMIA by past IMIA President Shigekoto Kaihara (Figure 1). The gavel is engraved with the names of all past IMIA presidents. The names span 51 years starting with François Grémy, who became president in 1968, and ending with my immediate predecessor Hyeoun-Ae Park and my own. When preparing to write this President's Statement for the 2018 IMIA Yearbook of Medical Informatics, I read over the names and reflected upon what an honor and challenge it is to step into the role of IMIA President.

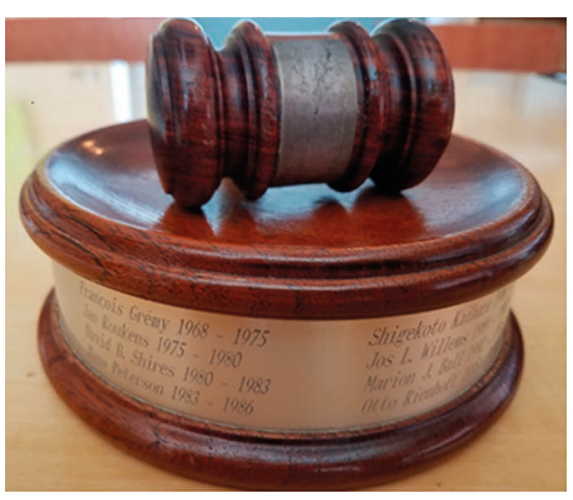

Fig. I IMIA President's Gavel

Since the founding of IMIA, half a century has passed bringing many changes in health information technology and informatics. In the words of one of my predecessors, Marion Ball from 1993, "The technologies may not be perfect, and probably never will be, but they are sufficiently mature to support real change in health care, far beyond academic settings" [1]. The global movement to implement electronic health records and new aspects of our field like genomics and phenomics with their associated challenges and opportunities make IMIA more relevant than ever before. IMIA serves as the organizer and convener of the international informatics community bridging distances between professionals operating in different spheres. IMIA provides the tools and vehicles to allow free exchange of ideas and research across borders and continents.

I want to use this space to discuss how IMIA will continue to fill this important role and support the dissemination of ideas in our field. IMIA's tools to support its mission include the MedInfo conference, the IMIA Yearbook of Medical Informatics, IMIA working groups, and now the International Academy of Health Sciences Informatics.

\section{Medlnfo}

Initially held every three years, MedInfo is now organized every two years and we are looking forward to our next meeting "The 17th World Congress of Medical and Health Informatics" in the "French Tech metropolis" of Lyon, hosted by the French Association for Medical Informatics (August 26-30, 2019). Please keep in mind that the deadline for submissions will be November 12, 2018.

The IMIA Board of Directors - recognizing the importance of the MedInfo meeting that draws presenters, researchers, students, implementers, and scientist from across the globe - will develop a white paper describing the basic requirements for MedInfo host countries in 2019. These requirements will include guaranteed safety and security for our attendees, freedom of travel, scientific freedom, commitment of the host country's national member organization, and the absence of discrimination (e.g., race, gender, disability, age and others). 


\section{Yearbook of Medical Informatics}

One of the pillars of IMIA in its mission to share and distribute knowledge has been the IMIA Yearbook of Medical Informatics. In 2018, the Yearbook was managed by an outstanding team of Vice President for Services, Brigitte Séroussi, and editors, Lina Soualmia and John Holmes. Next year Kate Fultz Hollis will replace John Holmes. We would like to thank John for his outstanding services and welcome Kate to the team.

IMIA is grateful to past IMIA President Prof. Reinhold Haux and his team at the Peter L. Reichertz Institute for Medical Informatics in Braunschweig, Germany, who labored to bring all past Yearbooks of Medical Informatics online. Thieme Verlag purchased IMIA's long-time publisher Schattauer and now hosts all Yearbooks starting from 1992 to today (26 years) online at https://tinyurl. com/y8mmwm8y.

\section{IMIA Working Groups}

IMIA working groups provide a significant contribution to the IMIA community. They are the primary mechanism through which IMIA pursues its scientific activity in specific fields of the domain of health and biomedical informatics. They contribute to the Yearbook and pursue independent work in their specific domain. Some working groups have their own conferences like the Nursing Informatics working group, which organized the recent International Conference on Nursing Informatics in Guadalajara, Mexico. IMIA Vice President Helen Wu manages IMIA working group activities.

\section{International Academy of Health Sciences Informatics}

The International Academy of Health Sciences informatics - also called "the Academy" - is the newest organization under the umbrella of IMIA [2]. The first fellows were elected into the inaugural class in 2017 and had their first meeting in April 2018 in Gothenburg, Sweden, graciously hosted by the European Federation for Medical informatics at its MIE conference, where 59 of the 119 members were present. The Academy is intended to recognize excellent leaders, stimulate research, exchange knowledge, educate the community, advise governments and non-governmental organizations, produce policies, and train the next generation of informaticians [2]. Currently, the academy is developing its leadership model and the process for inducting new fellows. We anticipate our next in person meeting in conjunction with the APAMI meeting in Colombo, Sri Lanka in October 2018 [3].

\section{MENAHIA}

On a final note, I am pleased to report that - after losing IMIA's regional organization in the Middle East in 2017 - we are excited that a new organization has formed that is seeking to become the regional representative in IMIA. The Middle East and North African Health Informatics Association (MENAHIA) is registered in Saudi Arabia and currently has two member organizations (Saudi Arabia and Pakistan). Many other organizations have declared their intent to join in the future including United Arab Emirates (UAE), Qatar, Oman, Bahrain, Kuwait, Jordan, Tunis, Syria, Lebanon, Libya, Palestine, Egypt, and Morocco.
The MENAHIA board members include Riyad Alshammari, President (Saudi Arabia), Hammad Durrani, Vice President (Pakistan), Dr. Najeeb Al-Shorbaji, General Secretary (Jordan), and Dr. Osama El Hassan, Treasurer (UAE). This new group already took it upon themselves to submit an extensive regional report for 2018 [4]. I am personally excited that more than 20 individuals from many countries jointly worked on this report. The IMIA Board already endorsed MENAHIA's request to become the regional representative in April 2018 and MENAHIA's request will be voted upon by the General Assembly in October at the APAMI meeting in Colombo, Sri Lanka [3].

\section{Conclusion}

Looking again at the gavel, I realize how many great leaders IMIA had over the years and I hope that I will be able to execute the office of President to your satisfaction. It is a humbling challenge but with your help and your advice, I am looking forward to it.

\section{References}

1. Ball MJ.A New IMIA Tradition. Yearb Med Inform 1993;2(1):1-2.

2. Lehmann CU, Park HA, Shortliffe EH, Degoulet P. The International Academy of Health Sciences Informatics: An Academy of Excellence. Yearb Med Inform 2017 Aug;26(1):7-8.

3. Asia-Pacific Association for Medical Informatics 2018 Conference. Available online at http:// dhw2018.org/apami2018/

4. Al-Shorbaji N, Househ M, Taweel A, Alanizi A, Mohammed BO, Abaza H, et al. Middle East and North African Health Informatics Association (MENAHIA): Building Sustainable Collaboration. Yearb Med Inform 2018. Available online at https:// www.thieme-connect.com/products/ejournals/ pdf/10.1055/s-0038-1641207.pdf 